\title{
BIRTHING BALL EXERCISE AND ITS CORRELATION ON LABOR PAIN
}

\author{
Susiana Yuni Astuti'), Uki Retno Budihastuti'), Hanung Prasetya3) \\ 1)Masters Program in Public Health, Universitas Sebelas Maret \\ 2)Department of Obstetrics and Gynecology, Dr. Moewardi Hospital/ \\ Faculty of Medicine, Universitas Sebelas Maret \\ 3) Study Program of Acupunture, Health Polytechnics, Ministry of Health Surakarta
}

\begin{abstract}
Background: Pain relief in labour was identified to be one of the most important topics related to pregnancy and childbirth. Birth ball is one of the non-pharmacologic pain relief methods to help mothers cope with the laboring process. It can ease sensations of pain by promoting women's well-being, comfort, and sense of control in labor. This study aimed to evaluate the effectiveness of birthing ball exercise and its correlation on labor pain.

Subjects and Method: This was a systematic review and meta-analysis. Using the PubMed, Science Direct, Google Scholar, and Springerlink database, a literature search was conducted for randomized control trial on the effect of birthing ball exercise on labor pain. The following search terms were used: ("birthing ball exercise") AND ("labor pain") AND ("randomized controlled trial"). The inclusion criteria were English full text and randomized controlled trial. The articles were filtered using PICO model, including: (1) Population= pregnant women aged 18-35 years, (2) intervention= birthing ball exercise, (3) comparison $=$ without birthing ball exercise, and (4) outcome $=$ labor pain. The inclusion criteria were English full-text, published from 2011 to 2020, and reported mean and standard deviation. The systematic review was carried out according to the PRISMA flow diagram. Data analysis were performed using RevMan 5.3.

Results: 6 studies from Unites States, Taiwan, Iran, Turkey, India, and Hongkong were involved for meta-analysis. This study showed that birthing ball exercise reduced labor pain 0.92 units than without birthing ball exercise (Standardized mean difference $=$ $0.92 ; 95 \% \mathrm{CI}=-1.28$ to $-0.56 ; \mathrm{p}=0.005$ ).
\end{abstract}

Conclusion: Birthing ball exercise significantly reduces labor pain.

Keywords: birthing ball exercise, labor pain

\section{Correspondence:}

Susiana Yuni Astuti. Masters Program in Public Health, Universitas Sebelas Maret. Jl. Ir. Sutami 36A, Surakarta 57126, Central Java. Email: susianayuni.a@student.uns.ac.id. Mobile : +6281390940681 .

The $8^{\text {th }}$ International Conference on Public Health

Solo, Indonesia, November 17-18, 2021 | 150

https://doi.org/10.26911/AB.Maternal.ICPH.08.2021.24 